\title{
Artigos \\ Ultrapassando Vedações e Resgatando Memórias
}

Sara Pargana Mota (Universidade de Coimbra)

\section{INTRODUÇÃO}

A Austrália foi uma colônia britânica a partir do final do século XVIII. Os povos indígenas haviam chegado há aproximadamente 60 mil anos quando, em 1788, os primeiros colonos, majoritariamente condenados, desembarcaram no continente. Os ingleses declararam que a Austrália era terra nullius - ou seja, sem habitantes humanos - e assim justificaram a apropriação das terras indígenas e a ocupação do continente. Tomaram como suas as terras férteis e forçaram os indígenas a habitar as zonas áridas do interior. Esta primeira fase da colonização da Austrália, na qual a terra foi apropriada, foi também caracterizada pela mortalidade indígena, atribuída a quatro motivos principais: homicídios, abusos sexuais, doenças e fome (Wolfe 1999). Os séculos seguintes continuaram a assistir à saída forçada dos povos indígenas australianos do seu território, das suas terras habitáveis, a vê-los mortos a tiro, envenenados, massacrados. A violação e o rapto de mulheres indígenas eram comuns. Nos finais do século XVIII, entre 250.000 a 750.000 indígenas australianos habitavam o continente mas, em 1911, estima-se que restavam apenas 31.000 (Tatz 1999). Numa lógica de eliminação, milhares de indígenas australianos perderam a vida. Os sobreviventes a estes genocídios foram segregados em missões cristãs e reservas. E, apesar de se ter verificado um aumento considerável da população indígena australiana desde 1911 até hoje, o seu nível de vida continua significativamente mais baixo do que a média nacional, e suas condições de vida permanecem deterioradas e empobrecidas.

Patrick Wolfe afirma que "o projeto da memorização nacional implicava, acima de tudo, o esquecimento do legado criminal do genocídio" (Wolfe 1999:33) . E ainda implica. A violência praticada contra os povos indígenas foi, de modo geral, suprimida nos escritos históricos Australianos do século $\mathrm{XX}$, em um culto de esquecimento praticado em escala nacional. Neste texto pretende-se refletir sobre duas importantes 
referências, o ensaio de Roslyn Poignant sobre o encarceramento de um grupo de indígenas australianos no mundo do espectáculo Ocidental, e o filme Rabbit-Proof Fence (2002), que rompem com o silêncio da memória indígena australiana e a resgatam.

\section{VIDAS CATIVAS E O ESPECTÁCULO DO MUNDO OCIDENTAL}

A corrente científica e filosófica do Evolucionismo supunha que as diferentes sociedades humanas podiam ser classificadas segundo uma mesma linha de evolução, compreendendo três estágios: o primitivo, o bárbaro e o civilizado. As formas mais antigas da sociedade humana teriam derivado de modificações das formas de organização social de outros primatas. Os povos indígenas da Austrália seriam exemplos atuais de como teriam sido as sociedades pré-históricas, servindo também de modelo comparativo ao que era considerado cultural e socialmente mais avançado (por afirmação da sociedade Ocidental), e ao que era considerado mais atrasado (por negação ou exorcismo da mesma).

As ideias dos povos indígenas, como selvagens ou primitivos, foram definidas através da justaposição de conceitos de civilização, criando uma relação hierárquica com a Europa e justificando a conquista imperial. No entanto, o papel das representações visuais na educação e no entretenimento popular como um meio de divulgar teorias científicas e de formular e legitimar políticas oficiais tem sido negligenciado em prol de um maior destaque às narrativas e descrições históricas textuais.

No livro Photography's Other Histories (2003), uma coleção de doze ensaios editada por Christopher Pinney e Nicolas Peterson, encontramos um ensaio de Roslyn Poignant sobre o papel da fotografia em criar e sustentar o estereótipo de "selvageria". Este ensaio encontra-se integrado na segunda seção do livro, designada por "Visual Economies", que examina a fotografia a serviço do colonialismo e que retira o seu nome de uma obra de Deborah Poole (1997), na qual ela explora as desigualdades que caracterizam os domínios representacionais. Esta expressão, "economia visual", além de acentuar as circunstâncias de desigualdade que deram origem à grande maioria das imagens presentes no arquivo colonial, permite também tornar visível a forma como as imagens visuais se movem ao longo de fronteiras nacionais e culturais.

Em "The Making of Professional Savages", Poignant (2003) toma como ponto de partida o acontecimento que, em Outubro de 1993, foi notícia de muitos jornais - a descoberta de um corpo embalsamado de um indígena australiano, chamado Tambo, no porão de uma casa funerária recentemente fechada, em Cleveland, Ohio. Este acontecimento despertou a atenção e a consciência pública para a história de Tambo e outros oito indivíduos Manbarra e Biyaygirri (Figura 1) levados de Queensland, Austrália, nos anos de 1880, por R. A. Cunningham, agente do lendário empresário de circo P. T. Barnum e que, em 1883, fizeram parte do seu espectáculo circense Ethnological Congress of Strange and Savages Tribes. Tratava-se de uma coleção não só do que se designava de "espécimes-tipo" da humanidade, de seres humanos de diferentes raças, mas que também exibia aqueles que possuíssem peculiaridades extraordinárias, como gigantes ou anões, percorrendo a América do Norte e a Europa. Tambo foi o primeiro a morrer, apenas um ano depois de ter sido levado da Austrália. 


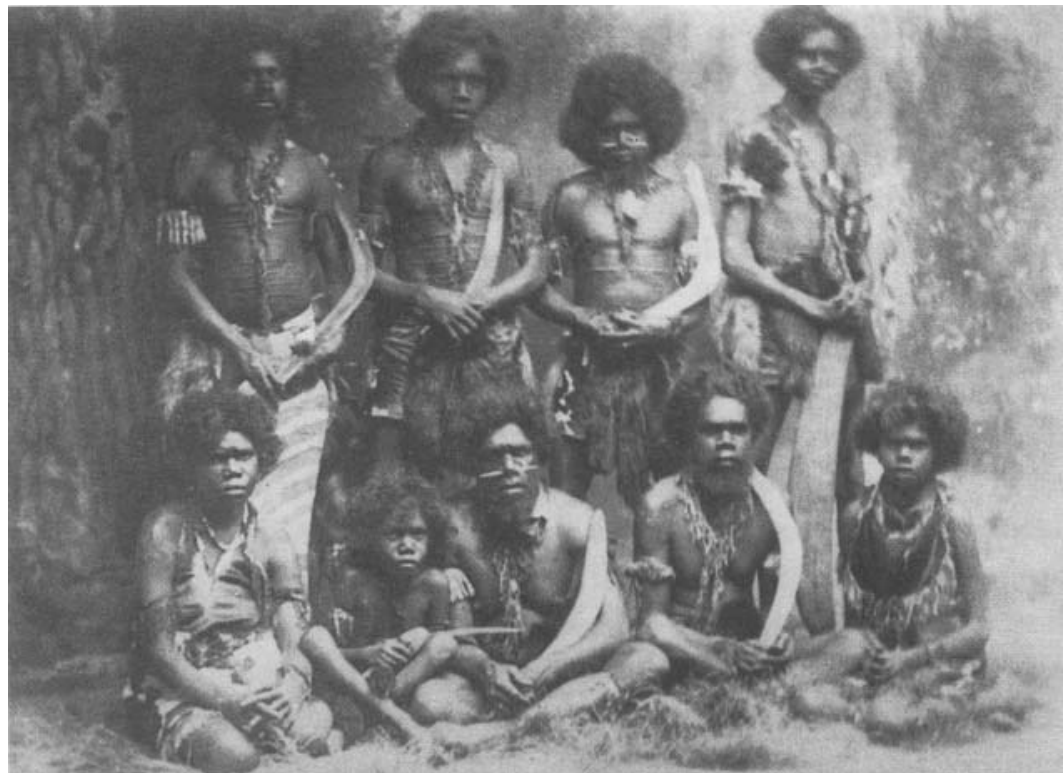

Figura 1. Única fotografia conhecida de todos os 9 indígenas retirados da Austrália por R. A. Cunningham, em 1883 (Poignant 2003:58).

Tentando recuperar a história perdida e fragmentada deste grupo de nove indígenas australianos, Roslyn Poignant examina, no processo, o fenômeno da exibição de povos indígenas, que surgiu e floresceu por volta dos anos de 1870, nos Estados Unidos e na Europa, revelando a extensão transnacional deste meio de circulação de ideias sobre a diferença humana. Nesta época, século XIX, os circos e as feiras mundiais constituíram-se como um meio importante através do qual aqueles que estavam no centro do Império poderiam satisfazer a sua curiosidade sobre aqueles "Outros" que viviam nas suas extremidades distantes. Estes espetáculos incluíam frequentemente exibições, não só de animais exóticos, mas também de povos exóticos, apresentados como curiosidades sob o manto da ciência, "sendo a venda de fotografias parte da exploração dos performers indígenas, juntamente com a venda de panfletos, roteiros de circo e artefatos" (Poignant 2003:59) . Nesta época, como argumenta a autora, "o circo era provavelmente o instrumento de cultura de massas mais influente em moldar as atitudes públicas, através de um conjunto extraordinário de atividades representacionais relacionadas" (Poignant 2003:70) .

Poignant ilustra como estes nove indígenas levados da Austrália por R. A. Cunningham eram feitos prisioneiros, não apenas no sentido da perda de agência, mas também dentro dos discursos do final do século $\mathrm{XIX}$ que ligavam as fronteiras coloniais aos centros metropolitanos da América do Norte e Europa. Nestes centros, eles, em conjunto com outros indivíduos de povos indígenas, eram (re)criados como performers para o beneficio 
das plateias Ocidentais. E uma vez que o espetáculo do canibalismo - o ato mais transgressivo da humanidade era central para o discurso colonial Ocidental, estes indígenas foram representados e expostos como "canibais" em circos, feiras e Dime Museums, e examinados e fotografados por antropólogos. As fotografias, os panfletos e os cartazes do circo, bem como a publicidade destes espetáculos impressa nos jornais, contribuíam para esta representação exotizante do grupo de indígenas australianos aplaudidos como canibais (Figura 2), construindo-os como "selvagens profissionais". Encarcerados no poderoso estereótipo construído de "selvageria", retratados como os selvagens idealizados da imaginação Ocidental dos finais do século XIX, satisfazendo as fantasias canibais das plateias, "eles tornaram-se enredados nos sistemas Ocidentais de entretenimento popular e educação envolvendo exibição e performance, que marcaram a emergência do mundo moderno como espectáculo" (Poignant 2003:56) . A autora designa de show-space este espaço cultural dentro do qual relações historicamente específicas de poder entre colonizadores e colonizados eram tornadas visíveis.

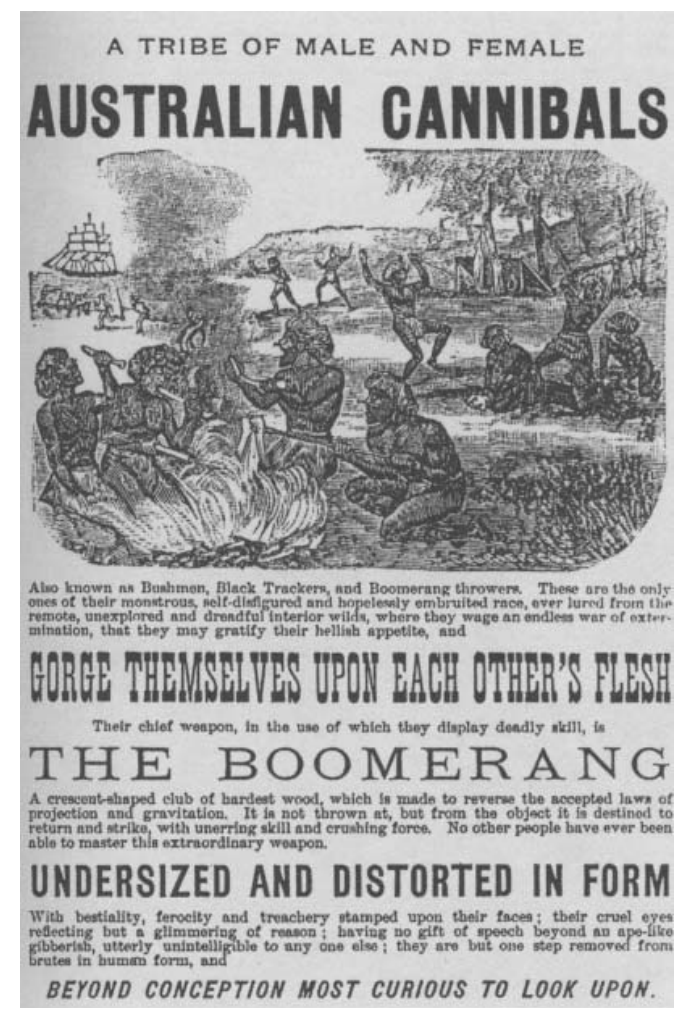

Figura 2. "Australian Cannibals", Advance Courier, 1883 (Poignant 2003:73). 
Neste espaço, as suas histórias pessoais eram também enredadas na relação entre a cultura popular e a Antropologia. As fotografias e as medições corporais realizadas por antropólogos ao grupo de indígenas de Cunningham faziam parte do projecto classificatório que postulava uma hierarquia de raças na qual os indígenas australianos eram associados ao grau mais primitivo. Estas noções evolucionistas forneceram a base ideológica que, em grande parte, legitimou este tipo de exposição e exploração. Nos dias de hoje, as fotografias e as descrições realizadas pelos antropólogos da época aos nove indígenas australianos surgem como documentos valiosos que possibilitam a identificação e a descoberta da sua individualidade.

Traçando os percursos destes performers indígenas australianos nos circuitos coloniais da Europa e da América do Norte, Roslyn Poignant tenta encontrar pistas da sua identidade, recuperando a sua agência, bem como a sua experiência do mundo em que foram imersos, reconstruindo as dimensões humanas desta tragédia. Sendo central na sua análise a investigação dos processos coloniais representacionais que transformaram estes indígenas australianos em "selvagens profissionais", nomeadamente o poder das representações visuais - gráficas e fotográficas - em fixar o estereótipo racial de selvagem, a narrativa textual é acompanhada por ilustrações e fotografias do arquivo colonial. A autora sugere que "é a sua interrogação [...] que ajuda a destabilizar a 'fixidez' e a romper com as imagens estereotipadas do grupo em ambas as formas, fotográficas ou gráficas, ao restituir-lhes algo da sua individualidade" (Poignant 2003:61). Através da interrogação das imagens exotizantes recuperadas do acervo colonial por Poignant, abre-se um espaço de re-significação de memórias e histórias pessoais. Estas fotografias, tiradas com propósitos comerciais e antropológicos (Figura 3), permitem-nos abrir uma janela para o drama destas almas que foram despojadas de tudo. Surgem como fragmentos representativos que possibilitam a redescoberta e a recuperação das histórias pessoais deste grupo, esquecidas na memória coletiva, trazendo as suas narrativas biográficas de volta ao conhecimento público, especialmente ao dos seus descendentes. Dos nove indígenas que foram levados da Austrália, apenas três regressaram. A maioria morreu durante a tournée, de tuberculose e outras doenças respiratórias exacerbadas pela exposição a climas frios. Este estudo de Roslyn Poignant e as fotografias que ela recuperou do arquivo, a maioria comissionadas por Cunningham, fornecem, nesta narrativa do particular, uma evidência da indignidade final do projecto colonial. 


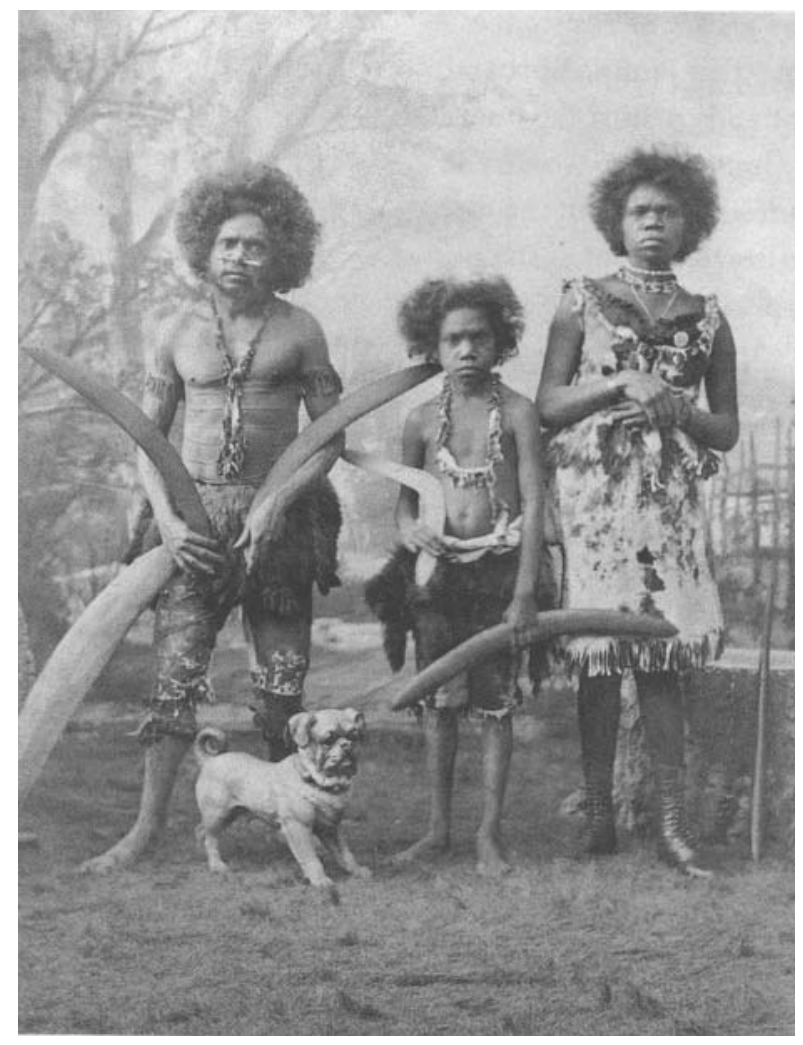

Figura 3. Billy, Jenny e Little Toby, fotografados pelo antropólogo Prince Roland Bonaparte, em Paris, 1885 (Poignant 2003:77).

\section{A MEMÓRIA CINEMATOGRÁFICA - RABBIT-PROOF FENCE}

A indústria de cinema australiana tem uma longa história e, pelo menos desde o seu renascimento nos anos 70, tem sido subsidiada pelo governo e intimamente associada à forma como os australianos percebem a sua cultura nacional. Como consequência, uma análise dos filmes australianos que lidam com temáticas e experiências indígenas oferece uma visão de como as atitudes não-indígenas relativamente à Austrália indígena têm mudado ao longo do tempo.

Enquanto muitos filmes australianos realizados sobre questões indígenas procuram explorar a sua sociedade contemporânea, recentemente o cinema australiano tem enfocado a memória do seu passado colonial. Surgiram nos últimos anos vários filmes históricos que examinam o passado e, por implicação, a sua relevância para as 
plateias contemporâneas. O filme Rabbit-Proof Fence (2002) aborda a política de assimilação e separação forçada de crianças indígenas mestiças das suas famílias, perpetrada pelo governo australiano entre as décadas de 1910 e 1970. Realizado por Phillip Noyce, o filme é baseado na história verídica de três crianças indígenas mestiças Mardudjara - Molly, Daisy e Gracie - que, em 1931, são separadas das suas mães em Jigalong, uma reserva indígena próxima de uma das vedações que estavam sendo construídas ao longo do continente australiano com o objetivo de tentar evitar que os coelhos destruíssem as quintas e zonas agrícolas, mantendo a praga de coelhos de um lado, e os bons terrenos de pastagem do outro. Retiradas à força das suas famílias por autoridades do governo, estas três jovens são levadas para a reserva de Moore River na Austrália Ocidental, a mais de 2000 km de distância, para serem preparadas como criadas domésticas e institucionalmente assimiladas na sociedade Australiana branca. Neste centro de reeducação, elas serão ensinadas a seguir o caminho do "dever, serviço e responsabilidade" que toda a mulher cristã deveria seguir, proibidas de falar a sua língua nativa, forçadas a abandonar a sua herança cultural, e ensinadas a ser culturalmente brancas. No entanto, estas três crianças conseguem fugir. Seguidas por um batedor indígena, Moodoo, e deparando-se com um percurso quase impossível de realizar, Molly, Gracie e Daisy não desistem do regresso para casa, atravessando uma paisagem desértica e inóspita, e, tendo a vedação como seu único guia, seguindo-a como um meio de regressar a Jigalong. Este filme tem poucos diálogos, apoiando-se mais em imagens, sons, e ritmos para narrar a história, sendo parte da sua visualidade uma ênfase em ícones, como a própria vedação - um ícone de múltiplas narrativas, com as suas ambiguidades e significados locais, nacionais e globais. O argumento deste filme é baseado no livro Follow the Rabbit-Proof Fence (1996) escrito por Doris Pilkington Garimara, a filha de Molly, em registros de arquivo e em registros orais, e no relatório da Comissão de Direitos Humanos e Igualdade de Oportunidades com o título de Bringing Them Home (HREOC 1997).

Em 1997, a Comissão de Direitos Humanos e Igualdade de Oportunidades publicou Bringing Them Home: Report of the National Inquiry into the Separation of Aboriginal and Torres Strait Islander Children from their Families, que documentou o que se designou na Austrália por "Gerações Roubadas", a remoção de crianças indígenas da sua cultura, bem como os legados das políticas de assimilação. Este relatório integrou as experiências pessoais de muitos indivíduos indígenas como evidência da remoção sistemática de crianças indígenas australianas das suas famílias, concluindo que, entre 1910 e 1970, milhares de crianças, especialmente de ascendência indígena e europeia, foram separadas à força de suas famílias e comunidades por autoridades ligadas ao governo.

No início do século $\mathrm{XX}$, as administrações coloniais na Austrália adotaram e implementaram políticas de proteção e segregação, com o objetivo de assimilar os indígenas na sociedade branca dominante. Como explica Stephen G. Baines, "na Austrália predominava a ideia de "absorver" os aborígines na sociedade nacional pelo desaparecimento de diferenças físicas e culturais, posta em prática através de duas políticas contraditórias: por um lado, pela separação forçada de crianças de suas mães aborígines (Australian Government, 1997), sobretudo os filhos mestiços ("half-casts") , com o objetivo de trazê-las à "civilização" pela ressocialização em instituições totais governamentais e de prepará-las para viver na sociedade nacional branca; por outro lado, através da política de segregação em reservas dos "full-bloods" (aborígenes de sangue puro), que se acreditava estarem em vias de 
desaparecer" (Baines 2003:117).

Como documentado no relatório (HREOC 1997), com receio do possível desastre de uma "terceira raça indesejada" de crianças indígenas mestiças, nos anos 1930 (época em que se desenrola a acção do filme) o governo Australiano, por determinação do Protector Chefe dos Assuntos Aborígenes, A. O. Neville (responsável legal por todos os Aborígenes no Estado da Austrália Ocidental), adotou a política oficial de separação forçada de crianças mestiças das suas famílias. Sua segregação foi feita pela relocação em instituições ou em famílias adotivas, para que fossem criadas como crianças brancas e absorvidas na população dominante. As meninas indígenas mestiças, segundo o plano de Neville, deviam ser retiradas das suas famílias e institucionalizadas e reeducadas em orfanatos, onde poderiam tornar-se "civilizadas", e "onde seriam treinadas em serviços domésticos para serem casadas posteriormente com homens brancos das classes operárias" (Baines 2003:118). Esta política tinha como objetivo "diluir" as características raciais de modo a "branquear" a população mestiça (Figura 4). Acreditava-se que a população aborígene full-blood, em declínio, estaria condenada a desaparecer. No entanto, o número de mestiços estava aumentando rapidamente, ameaçando o ideal político de uma "Austrália Branca". As crianças mestiças que permanecessem nas reservas aborígenes, entre as suas comunidades, teriam uma grande probabilidade de gerar uma descendência que propagasse esse "sangue aborígene puro". No entanto, se estas crianças fossem removidas e deslocadas para instituições específicas, elas iriam casar com outros mestiços ou mesmo brancos, de modo que os traços aborígenes pudessem vir a desaparecer. Eventualmente, esta política teria como resultado que a "raça" aborígene fosse praticamente eliminada (HREOC 1997; Wolfe 1999). Esta política de assimilação constituiu-se como uma política racista, eugênica e desastrosa, que originou o drama das chamadas "gerações roubadas". Como o relatório Bringing Them Home documenta, muitos dos indivíduos indígenas australianos que hoje em dia sofrem de alcoolismo, dependência de drogas e distúrbios psicológicos foram algumas destas "crianças roubadas", e continuam a sofrer os efeitos da destruição da sua identidade, família, vida e cultura.

O relatório da Comissão de Direitos Humanos e Igualdade de Oportunidades Bringing Them Home, que afirmou que estas políticas de separação forçada constituíram um genocídio segundo os termos da Convenção para a Prevenção e Punição do Crime de Genocídio de 1948, provocou um intenso debate dentro da esfera pública australiana, levantando um número de questões políticas, filosóficas e éticas significativas relativas à identidade nacional Australiana. O filme alargou e aprofundou o debate político iniciado com o relatório. Ao acentuar as realidades deste genocídio ocultado (inacreditavelmente, esta politica prolongou-se até ao início dos anos 70), Rabbit-Proof Fence surge como um poderoso testemunho do sofrimento das gerações roubadas, utilizando uma história para representar uma série de histórias semelhantes, elevando-a quase a um estatuto icônico. Foi o primeiro filme a lidar explicitamente com este assunto e a transportá-lo para uma arena internacional. 


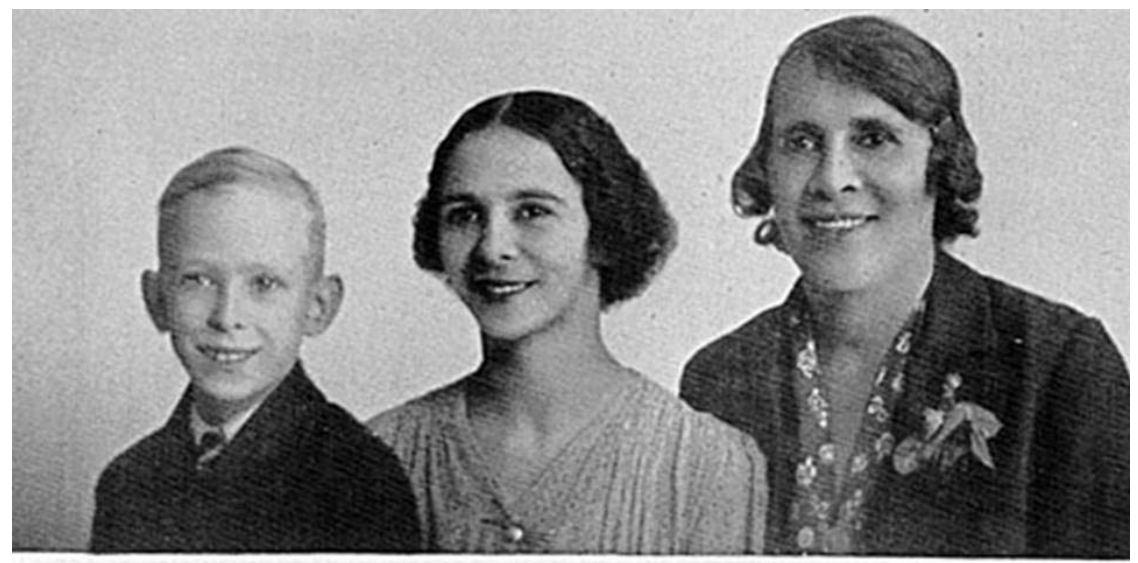

THREE GENERATIONS

(Reading from Right to Left)

1. Half-blood-(Irish-Australian father: full-blood Aboriginal mother).

2. Quadroon Daughter-(Father Australian born of Scottish parents; Mother No. 1).

3. Octaroon Grandson-(Father Australian of Irish descent; Mother No. 2).

Figura 4. De Australia's Colours Minority (1947) de A.O. Neville (Wolfe 1999:232).

Elizabeth Edwards (2001), na sua análise da relação entre fotografia, antropologia e "re-atuação", define este último conceito como "uma reconstrução performativa da ação social fora dos contextos normais e naturais e acontecimentos constitutivos" (Edwards 2001:157) , sendo a "re-atuação" também caracterizada por ser "um ato citacional, que remete para a ação social" (ibid.) e transforma um acontecimento passado não visto/não visível em uma representação visual para "ver" e "conhecer".

Parte do argumento de Rabbit-Proof Fence é baseado no livro Follow the Rabbit-Proof Fence, escrito por Doris Pilkington Garimara (1996) segundo as memórias da sua mãe Molly e da sua tia Daisy e, através da "re-atuação" da sua separação em Jigalong, o momento passado, já não existente, é reconstruído, restabelecido e transformado numa representação visual. A história torna-se real, visível, tangível. Aqui, a memória individual constitui uma fonte para reconstruir o passado histórico no tempo presente, reinvestindo-o de significado e poder de reflexão e acção.

Uma memória mais profunda evocada pelo filme é a do Holocausto. Como Tony Hughes D'Aeth argumenta, o filme tem certas semelhanças com o filme de Steven Spielberg Schindler's List (1993). Ele afirma que ambos os filmes "são fundados em relatos não-ficcionais (por Pilkington Garimara e Keneally) de acontecimentos traumáticos baseados em testemunhos de sobreviventes, [...] são ambos histórias de sobrevivência que têm lugar contra um 
pano de fundo de não-sobrevivência, ou histórias de fuga alternativas à condição geral de aprisionamento" (Hughes D'Aeth 2002) . O filme joga, junto à plateia, com a memória do Holocausto. Por exemplo, no filme as crianças são transportadas por comboio numa jaula para serem levadas para a reserva, enquanto segundo o livro de Pilkington, baseado nas memórias de Molly e Daisy, elas foram levadas de barco. O comboio surge como um elemento que a plateia recorda como o meio pelo qual os Nazis transportavam os Judeus para os campos de concentração. As próprias imagens da reserva de Moore River evocam comparações com Auschwitz e colocam como questão se a história das "gerações roubadas" constituiu o Holocausto Australiano. É de salientar, no entanto, que neste filme Noyce aborda o passado de forma muito cuidadosa, evitando uma dramatização da história colonial da Austrália baseada numa dicotomia como "Mal x Bem", optando por uma evocação sutil. Por exemplo, a personagem de A. $\mathrm{O}$. Neville, que ordenou a retirada de milhares de mestiços, é representada como um homem que genuinamente acreditava nos benefícios morais e civilizadores da sua missão e na superioridade inquestionável dos brancos sobre a cultura nativa. Para Neville e outros, esta política não surge como cruel ou inumana. Pelo contrário, Neville acredita e afirma que the native must be helped in spite of himself. Noyce também não passa ao lado da assimilação dos indígenas australianos na cultura Ocidental, ilustrada pela personagem do "batedor" Moodoo.

A dramatização de Noyce não se concentra tanto em uma raiva política, mas na simpatia emocional, concentrando-se na situação difícil das crianças, e não explorando a fundo a revolta contra as autoridades. Apesar de contar uma história australiana específica - pertencente às "gerações roubadas" e à White Australia Policy -, Noyce conta-a de uma forma onde estão presentes os elementos universais da tragédia e do heroísmo. $O$ filme tem uma história que é simultaneamente local, distintamente Australiana, mas também universal na representação da coragem contra a adversidade. Esta narrativa específica de um determinado tempo e espaço neste meio global acaba também por transformar singularidades em universais emocionais (Hughes-D'Aeth 2002; Schaffer \& Potter 2004). No cartaz para a estreia Norte-Americana do filme lê-se: What if the government kidnapped your daughter?, tendo sido digitalmente removida a imagem central da Molly e da Daisy (Figura 5). Numa linguagem de empatia, numa linguagem universal de emoções, "o filme como uma mercadoria conduz as audiências não-Indígenas em diversos locais a uma proximidade experiencial e a uma identificação empática com a experiência da Geração Roubada" (Schaffer \& Potter 2004). 

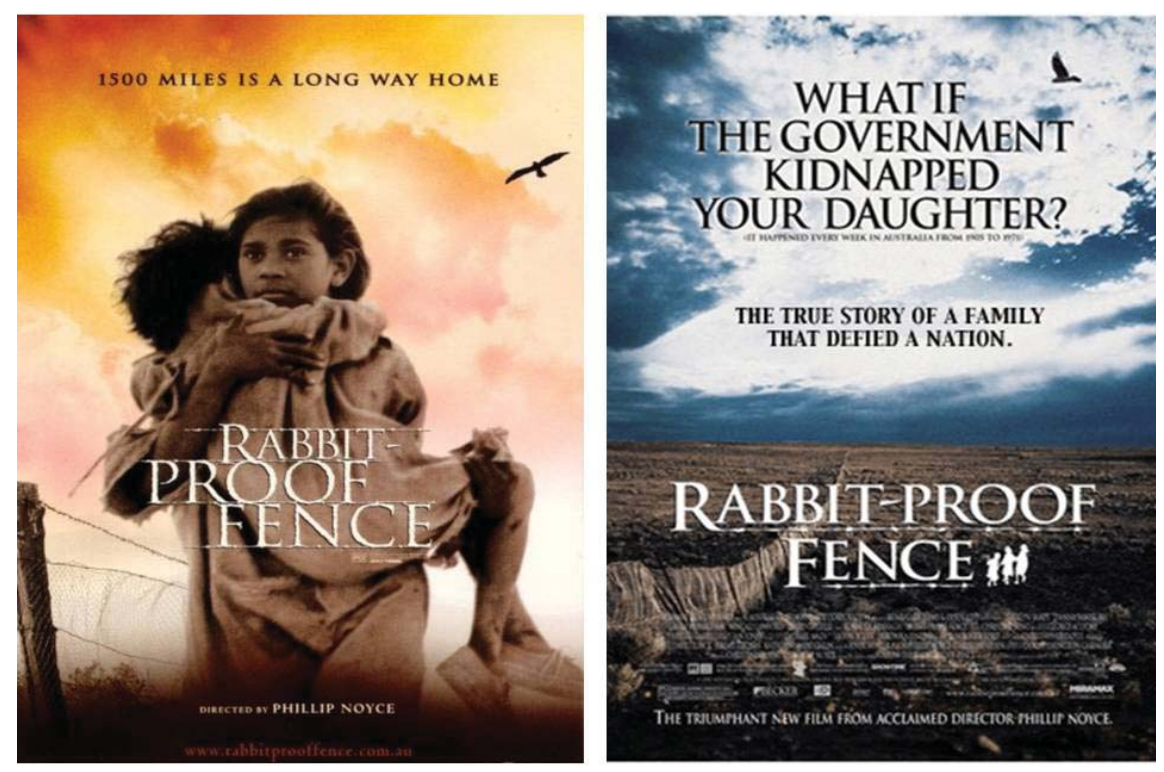

Figura 5. Cartaz do filme Rabbit- Proof Fence para a estreia na Austrália e na Europa (à esquerda) e para a estreia Norte-Americana (à direita) (Hughes-D'Aeth 2002).

Tony Hughes-D'Aeth (2002), na sua leitura do filme, argumenta que a empatia é aqui usada como uma forma de atrair as plateias e obter um sucesso comercial. $\mathrm{O}$ autor levanta algumas questões sobre os perigos das políticas da identificação pela empatia e sobre a forma como a indústria de cinema de Hollywood comercializa o trauma e homogeneíza e mercantiliza a experiência, universalizando uma história particular, empacotando a diferença como uma experiência universal coletivizada, e minando assim a responsabilidade de reconhecer a incomensurabilidade da experiência indígena. É certo que muitas vezes a indústria de cinema homogeneíza as particularidades em termos humanistas universais. É também certo que em muitos pontos-chave do filme RabbitProof Fence, como salientam Schaffer e Potter, "a plateia é convidada não apenas a identificar-se com a Molly e a experiência de ser roubada, ou de ter um filho a ser retirado de si, mas a ser de fato Molly, a ver o que ela vê e a sentir o que ela sente" (Schaffer \& Potter 2004). Assim, muitas cenas do filme são filmadas como se a câmara fosse os olhos de Molly e a audiência estivesse no interior das suas experiências. Por exemplo, no início do filme este efeito é utilizado durante a cena em que as três jovens são retiradas das suas mães, que foi filmada à altura de uma criança, com uma câmara manual, portátil, levando a audiência a imergir na cena traumática, colocando-a numa posição de identificação com as crianças. 
Mas, apesar de ser importante registar os perigos da mercantilização, que transforma singularidades em universais, e da identificação pela empatia, a decisão de Phillip Noyce de realizar a estreia do filme em Jigalong (onde estiveram presentes Daisy, Molly e a sua filha Doris) assinala a atenção e o tributo do filme à experiência indígena vivida, local - uma narrativa particular a um determinado tempo e espaço. No final do filme surge um novo espaço epistemológico - não o cinema, mas um modo fílmico que se aproxima do documentário, espaço este que reforça uma dimensão ético-política. O filme acaba também por implicar a nação australiana nos legados das histórias de "Gerações Roubadas". Na sua representação do sofrimento, Rabbit-Proof Fence procura colocar todos os australianos numa posição de relação e de responsabilidade pelos efeitos da assimilação nas vidas indígenas, como é visível na sua declaração final: We call them the Stolen Generations. Tanto no relatório Bringing Them Home, como no filme Rabbit-Proof Fence, como Schaffer e Potter argumentam, “o testemunho pessoal é mobilizado para uma adesão política, colocando a plateia, como ouvinte, numa relação ética com o narrador, [...] como testemunha 'na segunda pessoa' da experiência histórica. Neste compromisso dialógico de contar e ouvir, as testemunhas são levadas a reconhecer a história e a veracidade das narrações e a assumir a responsabilidade de defenderem a mudança social e política" (Schaffer \& Potter 2004) .

$\mathrm{O}$ argumento do filme, com uma representação realista das personagens e do contexto indígena australiano, é produzido segundo uma perspectiva indígena, porque baseado numa história escrita por uma mulher indígena. Pilkington-Garimara, autora do livro Follow the Rabbit-Proof Fence (1996) - que, para além do relatório Bringing Them Home, esteve na base do argumento de Rabbit-Proof Fence -, foi também consultora do filme, reformulando partes do argumento que ela considerava violar tabus culturais. Mas Pilkington, filha de Molly, não foi apenas a narradora da história da sua mãe, e uma mediadora na sua tradução para um produto fílmico Ocidental: ela própria foi parte das "Gerações Roubadas", tendo sido retirada da sua mãe anos mais tarde desta ter regressado a Jigalong.

Na sua narrativa fílmica, Rabbit-Proof Fence procura reconstruir a memória indígena australiana que, no presente, continua a sofrer as consequências das práticas perpetuadas pelas administrações coloniais. Uma memória onde, nos seus capítulos mais negros, a palavra perda continuamente se repete - perda do território, da cultura, da religião, da liberdade e dignidade, e perda dos seus próprios filhos. Uma outra história da Austrália, a história de um povo que, tal como os coelhos, foi obrigado a manter-se no seu lado da vedação.

\section{CONCLUSÃO}

As circunstâncias atuais dos indígenas australianos continuam assombradas pelo violento passado colonial da Austrália.

O realizador chileno de cinema documental, Patrício Guzman, que realizou a trilogia La Batalla de Chile (1975-1979) e o filme La Memoria Obstinada (1997), usou a memória das vítimas como um meio de desafiar o esquecimento oficial do governo. Para ele existe uma ligação direta entre a memória das vítimas e a capacidade da 
nação de se reconciliar com o passado e de construir um futuro melhor. Como ele afirma, “a memória é importante. A memória histórica de uma nação molda as suas expectativas. Pode ser terrivelmente doloroso falar de terrores e tragédias do passado. Mas a verdade inspira esperança. E esta inspira a vontade para a mudança social" (Guzman 2002 in McCarthy 2003:2) .

A investigação de Roslyn Poignant (2003) sobre o percurso de um grupo de indígenas australianos nos circuitos coloniais de entretenimento popular da Europa e América do Norte, com a sua recuperação de fotografias do arquivo colonial, possui um potencial redentor ao restituir a humanidade perdida deste grupo de nove indígenas que, no final do século XIX, foram exibidos em circos. Este resgate e o filme Rabbit-Proof Fence (2002), que lida com o processo histórico que se designou na Austrália por "Gerações Roubadas", tornam visível como as representações visuais podem emergir como agentes ativos na criação de espaços de interação e diálogo, no processo de inscrição de novos significados. Ambos contribuem para uma maior compreensão sobre a complexidade dos processos históricos, políticos, sociais, científicos e representacionais da história colonial da Austrália, e das diversas representações visuais a ela associadas, e acabam por ter um efeito catártico, ao dar voz a experiências e perspectivas que de outro modo permaneceriam silenciosas sob o manto da história.

McCarthy, na sua análise da relação entre memória individual e memória coletiva, acentua que, como os debates políticos sobre as "gerações roubadas" revelam, "a memória individual possui uma capacidade profunda de desafiar a memória coletiva da sociedade Australiana" (McCarthy 2003:2) . Libertar estas vozes e reconhecer histórias da realidade colonial opressiva é apenas um aspecto do trabalho necessário para a Austrália alcançar uma espécie de reconciliação com o seu passado e construir uma sociedade baseada no respeito pelos seus povos indígenas.

Sara Pargana Mota é doutoranda no Departamento de Antropologia da Faculdade de Ciências e Tecnologia na Universidade de Coimbra. 


\section{NOTAS}

1 "the project of national memorization was above all one of forgetting the criminal legacy of genocidal theft" (Wolfe 1999:33).

2 "the sale of photographs being part of the exploitation of indigenous performers, together with the sale of pamphlets, circus route books, and artefacts" (Poignant 2003:59).

3 "the circus was probably the most influential instrument of mass culture in shaping public attitudes, through an extraordinary range of linked representational activities" (Poignant 2003:70).

4 Estes museus eram instituições únicas de educação moral e de entretenimento que se tornaram populares nos finais do século XIX nos Estados Unidos. Designados como centros de entretenimento para a classe operária, exibiam o bizarro e o exótico, objetos estranhos e curiosidades naturais, expondo mesmo seres humanos vistos como "monstruosidades", com talentos ou características físicas "estranhas". Integrando freakshows, performances de circo, bem como outros meios de entretenimento, estes museus tinham como preço de entrada apenas 10 cêntimos (1 dime), daí a sua designação. P. T. Barnum fundou o primeiro Dime Museum em 1841.5"they became enmeshed in Western systems of popular entertainment and education involving display and performance, which marked the emergence of the modern world as spectacle" (Poignant 2003:56).

5 "they became enmeshed in Western systems of popular entertainment and education involving display and performance, which marked the emergence of the modern world as spectacle" (Poignant 2003:56)

6 "it is the interrogation of them [...] that helps to destabilize the 'fixity' and disrupt the stereotypical imaging of the group in either form, photographic or graphic, by returning something of their individuality to them" (Poignant 2003:61).

7 As categorias jurídicas de definição do grau de aboriginalidade na Austrália - full bloods e half-casts - expressavam uma linguagem biológica de "sangue" (Baines 2003). Half-blood e mixed-blood eram outras categorias ambíguas para classificar os mestiços (Wolfe 1999).

8 Patrick Wolfe (1999), ao salientar a forma como ciência, nomeadamente a Antropologia, produziu um conhecimento sobre os aborígenes que legitimou certas políticas e programas oficiais do governo, refere-se ao fato de que Spencer, que realizou etnografia entre os Arunta da Austrália Ocidental, foi não apenas um antropólogo, mas também um conselheiro para o Governo relativamente aos assuntos aborígenes. Em 1911, Spencer foi nomeado o Protetor Chefe dos Assuntos Aborígenes, e as suas recomendações tiveram efeito nas políticas de assimilação.

9 "a performative reconstruction of social action outside normal and natural contexts and constitutive happenings" (Edwards 2001:157)

10 "a citational act, referring back to social action" (ibid.).

11 "are based on non-fictional accounts (by Pilkington Garimara and Keneally) of traumatic events that were founded on survivor testimony, [...] they are both survivor stories that take place against a backdrop of non-survival, or alternatively escape stories that confound a more general condition of imprisonment" (Hughes D'Aeth 2002).

12 "the film as a commodity form brings non-Indigenous audiences in diverse locations into experiential proximity and empathic identification with a Stolen Generation experience" (Schaffer \& Potter 2004).

13 "the audience is invited to not just identify with Molly and the experience of being stolen, or of having one's own child taken away, but to actually be her, seeing what she sees and feeling what she feels" (Schaffer \& Potter 2004).

14 "personal testimony is mobilised for political affect, placing the audience, as listener, in ethical relation to the teller, [...] as witness 'in the second person' to historical experience. In this dialogic engagement of telling and listening, witnesses are provoked to acknowledge the story and the veracity of the tellers and to take responsibility for advocating social and political change" (Schaffer \& Potter 2004).

15 "Memory matters. The historical memory of a nation shapes its expectations. It may be terrible painful to speak of terrors and tragedies of the past. But the truth inspires hope. And that inspires the will for social change" (Guzman 2002 in McCarthy 2003).

16 "individual memory has a profound ability to challenge the collective memory of Australian society" (McCarthy 2003). 


\section{REFERÊNCIAS BIBLIOGRÁFICAS}

BAINES, Stephen Grant. 2003. “Organizações Indígenas e Legislações Indigenistas no Brasil, na Austrália e no Canadá". Arquivos do Museu Nacional 61(2): 115-128.

EDWARDS, Elizabeth. 2001. Raw Histories: Photographs, Anthropology and Museums. Oxford \& New York: Berg. GARIMARA, Doris Pilkington. 1996. Follow the Rabbit-Proof Fence. Brisbane: University of Queensland Press.

HUGHES-D'AETH, Tony. 2002. "Which Rabbit-Proof Fence? Empathy, Assimilation, Hollywood". Australian Humanities Review 27. Disponível em: <http://www.australianhumanitiesreview.org/archive/lssue-September-2002/ hughesdaeth.html>. Acesso em: 27 dez. 2009.

HUMAN RIGHTS AND EQUAL OPPORTUNITY COMMISSION (HREOC). 1997. Bringing Them Home: Report of the National Inquiry into the Separation of Aboriginal and Torres Strait Islander Children from their Families. Disponível em: <http://www.austlii.edu.au/au/special/rsjproject/rsjlibrary/hreoc/stolen/>. Acesso em: 10 dez. 2009.

MCCARTHY, Greg. 2003. The Obstinate Memory in Australian Films. School of History and Politics, University of Adelaide. Disponível em: <http://www.utas.edu.au/government/APSA/GMcCarthyfinal.pdf>. Acesso em: 27 dez. 2009.

POIGNANT, Roslyn. 2003. “The Making of Professional 'Savages' - From P.T. Barnum (1883) to the Sunday Times (1998)". In C. Pinney \& N. Peterson (eds.) Photography's Other Histories. Durham \& London: Duke University Press.

POOLE, Deborah. 1997. Vision, Race and Modernity: A Visual Economy of the Andean Image World. Princeton: Princeton University Press.

SCHAFFER, Kay; POTTER, Emily. 2004. “Rabbit-Proof Fence, Relational Ecologies and the Commodification of Indigenous Experience". Australian Humanities Review 31-32. Disponível em: < http://www.australianhumanitiesreview.org/ archive/lssue-April-2004/schaffer.html>. Acesso em: 27 dez. 2009.

TATZ, Colin. 1999. "Genocide in Australia". Journal of Genocide Research 1(3): 315-352.

WOLFE, Patrick. 1999. Settler Colonialism and the Transformation of Anthropology - The Politics and Poetics of an Ethnographic Event. London \& New York: Cassel.

\section{FILMOGRAFIA}

GUZMAN, Patrício. 1997. Chile, La Memoria Obstinada. Canadá/França: La Sept-Arte/ Les Films d'Ici/ National Film Board of Canada (NFB). 52 min.

1975-1979. La Batalla de Chile. Chile/França/Cuba: Equipo Tercer Amo / Instituto Cubano del Arte e Industrias Cinematográficos (ICAIC). 3 partes. $264 \mathrm{~min}$.

NOYCE, Philip. 2002. Rabbit-Proof Fence. Austrália: Rumbalara Films / Showtime Australia production / Miramax. $94 \mathrm{~min}$.

SPIELBERG, Steven. 1993. Schindler's List. Estados Unidos: Universal Pictures / Amblin Entertainment 


\section{Ultrapassando Vedações e Resgatando Memórias}

\section{RESUMO}

Neste texto pretende-se refletir sobre a importância das representações visuais na redescoberta e recuperação de histórias do violento passado colonial da Austrália, reinvestindo-as de significado e poder de reflexão e ação. Com este objetivo, exploram-se duas importantes referências: a investigação de Roslyn Poignant sobre o encarceramento de um grupo de indígenas australianos no mundo do espectáculo Ocidental, com a sua recuperação de fotografias do arquivo colonial, e o filme Rabbit-Proof Fence (2002), que lida com o processo histórico que se designou na Austrália por "Gerações Roubadas" - exemplos que procuram romper com o silêncio da memória indígena australiana e resgatá-la.

PALAVRAS-CHAVE: Indígenas australianos; representações visuais; histórias, recuperação, memória.

\section{Breaking Seals and Rescuing Memories}

\section{ABSTRACT}

This article intends to reflect on the importance of visual representations in the rediscovery and recovery of histories born out of the Australia's violent colonial past, reinvesting them with meaning and power of reflection and action. With this objective, I explore two important references: the research of Roslyn Poignant about the imprisonment of a group of Indigenous Australians in the world of Western spectacle, with her recovery of photographs from the colonial archive, and the movie Rabbit-Proof Fence (2002), which deals with the historical process that was designated in Australia by "Stolen Generations", examples that seek to break the silence of indigenous Australian memory and rescue it.

KEYWORDS: Indigenous Australians, visual representations, histories, recovery, memory . 